Link article (Style APA): Shamych O. M. (2020). Gender peculiarities of Paralympic athletes' self-realization. Insight: the psychological dimensions of society, 4, 145-158. DOI: 10.32999/2663-970X/2020-4-9

Link article (Style DSTU 8302: 2015): Shamych, O. M. Gender peculiarities of Paralympic athletes' self-realization. Insight: the psychological dimensions of society, 2020, 4, 145-158. DOI: $10.32999 / 2663-970 X / 2020-4-9$

UDC 159.922.1:796.032.2-056.26

\title{
Gender peculiarities of Paralympic athletes' self-realization
}

\section{Гендерні особливості самореалізації паралімпійців}

\author{
Received: August 30, 2020 Accepted: November 06, 2020
}

\author{
Shamych Oleksandr Mykolaiovych \\ Candidate of Pedagogical Sciences, \\ Associate Professor \\ Department of Physical Education and Sports \\ Kyiv National University of Construction \\ and Architecture, Ukraine \\ sashamych@gmail.com, \\ ORCID 0000-0002-2188-2159
}

\author{
Шамич Олександр Миколайович \\ доктор психологічних наук, доцент \\ завідувач кафедри фізичного виховання \\ і спорту \\ Київського національного університету \\ будівництва і архітектури, Україна \\ sashamych@gmail.com, \\ ORCID 0000-0002-2188-2159
}

\begin{abstract}
The purpose is to compare the emotional states of male and female Paralympic athletes as well as to determine the gender psychological peculiarities of Paralympic athletes' self-realization in sports.

Methods. It has been used the author's questionnaire and six methods of psychodiagnostics: General Self-Efficacy Scale (R. Schwarzer, M. Jerusalem), Ryff's Psychological Well-Being Scale (adapted by T. D. Shevelenkova and T. P. Fesenko), Self-Determination Scale (Ye. M. Osina), S. Maddi's Hardiness Survey (adapted and translated by D. O. Leontiev, O. I. Rasskazova), Questionnaire of Self-Organization of Activities by 0. Yu. Mandrykova, Purpose in Life Test by J. Crumbaugh\& L. Maholick (adapted and translated by D. O. Leontiev). Results. It has been established that a set of factors caused by the disability fact has a more adverse effect on male Paralympic athletes than female ones; this needs
\end{abstract}

\begin{abstract}
Анотація
Мета. Порівняти емоційні стани спортсменів-паралімпійців чоловічої та жіночої статі. Визначити гендерні психологічні особливості спортивної самореалізації паралімпійців.

Методи. Було використано, розроблений нами, опитувальник та шість психодіагностичних методик: Шкала самоефективності Р. Шварцера та М. Єрусалема, Шкала психологічного благополуччя К. Ріфф (адаптація Т.Д. Шевеленкової і Т.П. Фесенко), Шкала самодетермінації (Є.М. Осіна), Тест життєстійкості С. Мадді (переклад і адаптація Д.0 Леонтьєва, О.I. Рассказової), Опитувальник самоорганізації діяльності (ОСД) О.Ю. Мандрикової, Тест “Смисложиттевих орієнтацій” (СЖО) Дж. Крамбо та Л. Махоліка (адаптація Д. О. Леонтьєва). Результати: Встановлено, що для чоловіків-паралімпійців негативний вплив комплексу чинників, пов'язаних з наявністю інвалідності, $є$ суттєво істотнішим, ніж для жінок, i, безумовно, потребує
\end{abstract}


in depth analysis and interpretation, taking into account that differences in performance indicators of healthy men and women are less noticeable. As for general features of self-realization of Paralympic athletes in sports, it is marked that Paralympic athletes are characterized by the predominant satisfaction with their sports career, a quite prompt setting of new sports goal and clear vision of the athletic future. It is also worth marking that most of them don't consider the achieved sports results as high as possible, because they realize their potential for further athletic development. It refers both to men and women. Conclusions. The findings can be useful for enhancing the performance and attitude of coaches of Paralympic representative teams to men and women during the training and competitive process of Paralympic athletes and contributing to their self-realization. Prospects for further researches involve analyzing and understanding why a set of factors caused by the disability fact has a more adverse effect on male athletes than female ones.

Key words: Paralympic athletes, gender peculiarities, self-realization, Paralympic sports.

\section{Introduction}

It is well known that one in ten inhabitants of the Earth is a person with a disability that is, on average, one in four families has such a member (Briskin, 2007; Mariasova, 2013). In Ukraine, the number of people with disabilities is constantly growing; it has already exceeded 2.8 million. It is marked that approximately half of them have first and second degree of disability - they are formally not capable of managing their existence due to the incompetency to work (Briskin, 2007).

Adisability'sconsequenceisnotonlythe damage of functions or structures of the organism but also, as a rule, the emergence of significant problems concerning the full functioning of a person with a disability as a member of the society (Dad'ova, 2007; Mariasova, 2013).

Scientists are unanimous that adaptive physical culture and sports are one of the most important focus areas which can lay the groundwork for the selfrealization and socialization of people with disabilities to a greater extent, neutralize negative changes of their psycho-emotional state, create preconditions for the physical and psychic adaptation to new living conditions (Mariasova, 2013; Ovcharenko, 2005). більш поглибленого аналізу та осмислення, оскільки нормативні відмінності між здоровими чоловіками та жінками є значно менш вираженими. Щодо загальних особливостей спортивної самореалізації паралімпійців установлено, що для паралімпійців у цілому властива переважна задоволеність власною спортивною кар'єрою, достатньо швидка постановка нової спортивної мети та досить чітке уявлення свого спортивного майбутнього. Також природно, що значна їх частина не вважає наявні спортивні досягнення гранично можливими, вбачаючи в собі потенціал для подальшого спортивного удосконалення. Це відноситься, як до чоловіків, так і до жінок. Висновки. Отримані результати можуть бути використані з метою підвищення ефективності та ставленню тренерів паралімпійських збірних команд до чоловіків і жінок в тренувально-змагальному процесі паралімпійців, а також для сприяння їх самореалізації. Перспективи подальших досліджень полягають у аналізі та осмисленні, чому для чоловіків-паралімпійців негативний вплив комплексу чинників, пов'язаних з наявністю інвалідності, є суттєво істотнішим, ніж для жінок.

Ключові слова: паралімпійці, гендерні особливості, самореалізація, паралімпійський спорт.

\section{Вступ}

Загальновідомо, що кожен десятий мешканець Землі є людиною з інвалідністю, тобто в середньому така людина $є$ в кожній четвертій родині (Бріскін, 2007; Марьясова, 2013). В Україні кількість людей 3 інвалідністю постійно зростає і вже перевищила позначку 2,8 млн. Зазначається, що приблизно половина з них $€$ з інвалідністю I та II груп, які формально не здатні забезпечити власне існування, оскільки не здатні працювати (Бріскін, 2007).

Наслідком інвалідності $\epsilon$ не тільки ушкодження функцій або структур організму, але i, як правило, виникнення істотних проблем щодо повноцінності функціонування людини 3 інвалідністю як члена суспільства (Dad’ova, 2007; Марьясова, 2013).

Дослідники одностайні в тому, що одним 3 найважливіших напрямів роботи, здатним великою мірою забезпечити умови для самореалізації та соціалізації людей 3 інвалідністю, нівелювати негативні зміни Ïх психоемоційного стану, створити передумови для фізичної і психічної адаптації до нових умов життя, $є$ адаптивна фізична

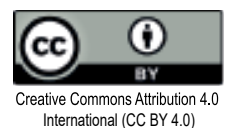


Gender peculiarities of Paralympic athletes' self-realization

In particular, Paralympic sports became a hefty boost for people with serious health problems or injuries to mobilize reserve capacities of the body and to realize the prospects for coming through their diseases and full integration into the society (Briskin, 2007, Ovcharenko, 2005). It plays an essential socializing and informative role by bringing the public's attention to the issues of disability, barrier-free environment, support of dignity, rights and well-being of people having the status of a person with a disability (Mariasova, 2013). The humanistic sense of various sports competitions involving people with disabilities is invaluable, because they allow such people "to be back to the society" (Dad'ova, 2007; Shuba, 2013).

A full integration of people with disabilities (both men and women) and its maintenance in different social institutions can be regarded as one of the central problems of modern society. The experts in such scientific and scientificpractical fields as psychology, pedagogy, social work and sports etc. are actively engaged in dealing with this problem. Nowadays, it has been convincingly proven that the involvement of people with disabilities into adaptative physical culture and sports makes it possible to lay the groundwork for their full self-realization and socialization to a greater extent, neutralize negative changes of their psycho-emotional state. Scientists from different countries confirm this fact in their researches (Boyko, 2012; Mariasova, 2013; Ondrušova et al., 2013).

At the same time, not in every instance men and women have similar approaches to the solution of the assigned tasks. There is a lack of studies aimed at ensuring the relevant scientific support of not only a comprehensive competitive and training process of a Paralympic athlete but also a full integration of the Paralympic athlete into the society through the means of Paralympic sports that is of critical importance. Thus, the research of psychological and socio-psychological focus, especially those which are oriented to the identification of gender psychological particularities, indicators and preconditions for Paralympic athletes' selfrealization in sports, become relevant.

The purpose is to compare the emotional states of Paralympic male and female athletes

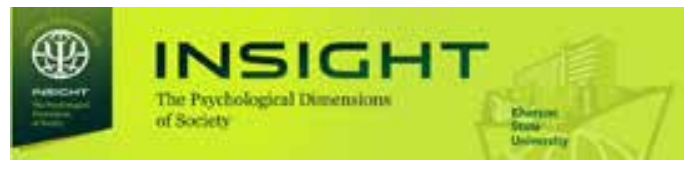

культура і спорт (Марьясова, 2013; Овчаренко, 2005).

Зокрема, потужним стимулом для мобілізації резервних можливостей організму, для усвідомлення людей 3 важкими недугами або травмами перспектив до подолання своїх хвороб та повноцінного інтегрування у суспільство став паралімпійській спорт (Бріскін, 2007; Овчаренко, 2005). Він відіграє важливу соціалізуючу та інформуючу роль, привертаючи увагу громадськості до проблем інвалідності, безбар'єрного середовища, підтримки гідності, прав і благополуччя людей, що мають статус людини 3 інвалідністю (Марьясова, 2013). Гуманістичний сенс різноманітних спортивних змагань осіб з інвалідністю $\epsilon$ безцінним, оскільки вони дозволяють таким людям “повернутися в суспільство" (Dad'ova, 2007; Шуба, 2013).

Повноцінне інтегрування та його забезпечення у різні суспільні інституції людей з інвалідністю, як чоловіків так і жінок, можна вважати однією 3 найбільш пріоритетних проблем сучасного суспільства. У вирішенні цієї проблеми беруть активну участь фахівці таких наукових та науково-практичних галузей як психологія, педагогіка, соціальна робота, фізична культура та спорт тощо. На сьогодні переконливо доведено, що залучення людей з інвалідністю до занять адаптивною фізичною культурою і спортом надає можливість істотною мірою забезпечити умови для їх повноцінної самореалізації та соціалізації, створенню передумов для ефективної фізичної і психічної адаптації, нівелювання негативних змін психоемоційного стану. Науковці різних країн показують це у своїх дослідженнях (Бойко, 2012; Марьясова, 2013; Ondrušova та ін., 2013).

Але не завжди однакові підходи до вирішення поставлених задач $є$ у чоловіків і жінок. Відчувається нестаток досліджень, покликаних створити необхідне наукове забезпечення не тільки повноцінного тренувально-змагального процесу паралімпійця, але й, що надзвичайно важливо, забезпечення засобами паралімпійського спорту повноцінного інтегрування паралімпійця до суспільства. Тому безумовно актуальними стають дослідження психологічного та соціально-психологічного 
as well as to determine the gender peculiarities of Paralympic athletes' self-realization in sports.

\section{Methodology}

It plays an essential socializing and informative role by bringing the public's attention to the issues of disability, barrier-free environment, support of dignity, rights and well-being of people having the status of a person with a disability (Mariasova, 2013). The humanistic sense of various sports competitions involving people with disabilities is invaluable, because they allow such people (both men and women) "to be back to the society" (Dad'ova, 2007; Shuba, 2013). For Paralympic athletes, sports turn into vitally important source of self-realization and existence, an essential means of posttraumatic restoration, adaptation, integration and social inclusion. The close interaction with healthy athletes offers opportunities for the establishment of new friendly relations, enhancement of life satisfaction and balancing of disability effects (Ondrušova et al., 2013).

Due to the marked organizational and psychological specifics, a training-competitive process puts particular demands for a personality of Paralympic athletes. As the disability limits the ability to do physical exercises, the achievement of top results requires of Paralympic athletes to observe well-defined regulations both of sporting and other activities, superior and constant manifestation of strong efforts, and permanent adhering to a wide range of restrictions and prohibitions that differently influence the emotional states of athletes depending on a gender (Ondrušova et al., 2013; Semerjian, 2010). It is marked that both male and female Paralympic athletes have a high level of altruism, readiness to help to others, cooperative endeavor, sense of responsibility, friendly attitude to people around, self-esteem, independence from the opinion of others, self-actualization, sociability, constructivism, a sense of purpose, self-belief, life quality and psychosocial adaptation (Mariasova, 2013; Maslov \& Pudovskyi, 2011).

Among the differences in the psychological state of a male and female Paralympic athletes, it was found pronounced sexual dimorphism in the context of gender analysis of aggression спрямування, зокрема, спрямовані на визначення гендерних психологічних особливостей, індикаторів та передумов спортивної самореалізації паралімпійців.

Мета. Порівняти емоційні стани спортсменів-паралімпійців чоловічої та жіночої статі. Визначити гендерні психологічні особливості спортивної самореалізації паралімпійців.

\section{Методологія дослідження}

В мобілізації резервних можливостей організму та усвідомленні людей, які мають важкі недуги або травми перспектив до подолання своїх хвороб та повноцінного інтегрування у суспільство, потужним та беззаперечним стимулом став паралімпійській спорт. Він відіграє важливу соціалізуючу та інформуючу роль, привертаючи увагу громадськості до проблем інвалідності, безбар'єрного середовища, підтримки гідності, прав і благополуччя людей, що мають статус людини з інвалідністю. Гуманістичний сенс різноманітних спортивних змагань осіб з інвалідністю $є$ безцінним, оскільки вони дозволяють таким людям, як чоловікам так і жінкам, "повернутися в суспільство" (Dad'ova, 2007; Овчаренко, 2005). Для паралімпійців спорт стає життєво важливим джерелом самореалізації та існування, важливим засобом посттравматичного відновлення, адаптації, інтеграції та соціальної інклюзії. Завдяки тісній взаємодії із здоровими спортсменами відкриваються можливості для створення нових дружніх стосунків, підвищення задоволення життям і компенсування наслідків інвалідності (Ondrušova та ін., 2013).

Внаслідок вираженої організаційної та психологічної специфіки, особливі вимоги до особистості паралімпійців ставить тренувально-змагальний процес. Оскільки інвалідність обмежує здатність виконувати фізичні вправи, досягнення високих результатів потребує від атлетів-паралімпійців дотримання чіткої регламентації як спортивної, так і інших видів діяльності, виключного та постійного прояву вольових зусиль, постійного дотримання цілої низки обмежень і заборон, що по-різному відображається на емоційних станах спортсменів в залежності від статі (Ondrušova та ін., 2013; Semerjian, 2010). Також зазначимо, що як

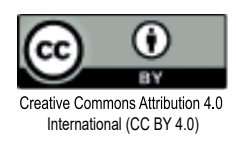


Gender peculiarities of Paralympic athletes' self-realization

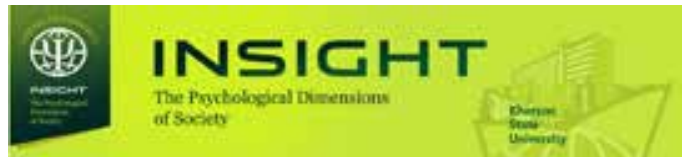

manifestation. Almost all individual types of aggression are peculiar to men, specifically physical, self-aggression and emotional aggression. And women, on the contrary, have average and low levels of aggression - emotional, verbal and self-aggression is notably low among others. Most participants showed an average level of general aggression, but it was much more typical for men than women. Men had a high level of general aggression, and none athlete manifested its low level, but female athletes did that confirmed better adaptive capacities of women's body (Lukovska, 2017).

The most appropriate methodological framework for the comprehensive study of personality's self-realization, both of men and women, in Paralympic sports includes the systems approach and the application of methodological principles of synergetics (Serdyuk, 2012 et al.).

Participants. 106 members of Paralympic and Deaflympics national teams of Ukraine in various sports (aged 16-53 years; among them - 84 men and 22 women) having different ICD diseases participated in the research.

Procedure and tools. It has been used the author's questionnaire and six methods of psychodiagnostics: General Self-Efficacy Scale (R. Schwarzer, M. Jerusalem), Ryff's Psychological Well-Being Scale (adapted by T. D. Shevelenkova and T. P. Fesenko), Self-Determination Scale (Ye. M. Osina), S. Maddi Hardiness Survey (adapted and translated by D. O. Leontiev, O. I. Rasskazova), Questionnaire of Self-Organization of Activities by $\mathrm{O}$. Yu. Mandrykova, Purpose in Life Test by J.Crumbaugh \&L. Maholick(adapted and translated by D. O. Leontiev).

To achieve the tasks of the empirical research, which has determined the factors of Paralympic athletes' self-realization in sports, the author has developed the questionnaire focused on the identification of the level and factors of selfrealization in athletic activities. The questionnaire can be used for the work both with athletes with disabilities and healthy athletes. The questionnaire sample is below (Fig. 1).

A demographic part of the questionnaire is intended to receive information about a respondent's age, sex, sports, training experience, у чоловіків, так і у жінок, у паралімпійців дуже високі рівні альтруїзму, готовності допомагати оточуючим, прагнення до співпраці, почуття відповідальності, доброзичливого ставлення до оточуючих, самооцінки, незалежності від думки інших, самоактуалізації, комунікабельності, конструктивізму, цілеспрямованості, впевненості в собі, самооцінки, якості життя та психосоціальної адаптації (Марьясова, 2013; Маслов, Рудовский, 2011).

Серед відмінностей психологічного плану між чоловіками та жінками паралімпійцями, при гендерному аналізі проявів агресії виявлено виражений статевий диморфізм. У чоловіків практично за всіма окремими видами агресії переважав іï високий рівень, особливо фізичної, самоагресії і емоційної агресії. У жінок, навпаки, переважали середній і низький рівні агресії, за видами особливо низькими були емоційна, вербальна і самоагресія. У більшості обстежених спостерігався середній рівень загальної агресії, але у чоловіків він виявлявся значно частіше, ніж у жінок. У чоловіків рівень загальної агресії був високим, а її низький рівень не реєструвався в жодного атлета, але був відзначений у досліджених спортсменок, що свідчило про кращі адаптивні можливості жіночого організму (Луковська, 2017).

Найбільш придатною методологічною основою для цілісного вивчення самореалізації особистості, як чоловіків, так і жінок, в паралімпійському спорті $\epsilon$ методологія системного підходу і застосування методологічних принципів синергетики (Сердюк, 2012 та ін.).

Учасники. В нашому дослідженні брали участь 106 членів паралімпійської та дефлімпійської збірних команд України з різних видів спорту (віком 16-53 роки; з них - 84 чоловіки та 22 жінки) та різних нозологій.

Процедура та інструменти. В дослідженнях було використано, розроблений нами, опитувальник та шість психодіагностичних методик: Шкала самоефективності Р. Шварцера та М. Єрусалема, Шкала психологічного благополуччя К. Ріфф (адаптація Т.Д. Шевеленкової і Т.П. Фесенко), Шкала самодетермінації (Є.М. Осіна), Тест життєстійкості С. Мадді (переклад і адаптація Д.О Леонтьєва, 
The questionnaire for the identification of the level and factors of self-realization in sports

Full name

age _ sex sports

Training experience

Athletic category

Top achievement at the All-Ukrainian level

Top achievement at the international level

PROCEDURE: Please, answer the questions below by circling the relevant statement (only one that is the most appropriate for every question).

\begin{tabular}{|c|c|c|c|c|c|c|}
\hline № & Questions & & & swer options & & \\
\hline 1 & $\begin{array}{l}\text { Satisfaction with the } \\
\text { personal sports career }\end{array}$ & dissatisfied & $\begin{array}{c}\text { rather } \\
\text { dissatisfied }\end{array}$ & $\begin{array}{c}\text { difficult to } \\
\text { answer }\end{array}$ & rather satisfied & fully satisfied \\
\hline 2 & $\begin{array}{l}\text { How rapidly do you set } \\
\text { a new sports goal after } \\
\text { the achievement of the } \\
\text { intended one? }\end{array}$ & never set & Long after & $\begin{array}{l}\text { after a } \\
\text { while }\end{array}$ & Soon enough & almost at once \\
\hline 3 & $\begin{array}{l}\text { How firmly do you } \\
\text { envisage your sports } \\
\text { career? }\end{array}$ & $\begin{array}{l}\text { I don't envisage } \\
\text { at all }\end{array}$ & $\begin{array}{l}\text { I almost don't } \\
\text { envisage }\end{array}$ & $\begin{array}{l}\text { in general } \\
\text { terms }\end{array}$ & $\begin{array}{l}\text { I tend to } \\
\text { envisage }\end{array}$ & $\begin{array}{l}\text { I have a clear } \\
\text { picture }\end{array}$ \\
\hline 4 & $\begin{array}{l}\text { Have you reached the } \\
\text { pinnacle of sports } \\
\text { achievement? }\end{array}$ & not at all & partially & $\begin{array}{c}\text { considerabl } \\
\mathrm{y}\end{array}$ & almost & fully \\
\hline 5 & $\begin{array}{l}\text { Your relations with } \\
\text { members of sports } \\
\text { group/team }\end{array}$ & bad & not very good & normal & good & very good \\
\hline 6 & $\begin{array}{l}\text { Your relations with } \\
\text { a coach (coaches) }\end{array}$ & bad & not very good & normal & good & very good \\
\hline 7 & $\begin{array}{l}\text { Your relations with } \\
\text { support staff }\end{array}$ & bad & not very good & normal & good & very good \\
\hline 8 & $\begin{array}{l}\text { The level of your interest } \\
\text { in workout }\end{array}$ & low & below average & average & high & very high \\
\hline 9 & My financial standing & bad & not very good & normal & good & very good \\
\hline 10 & My living conditions & bad & not very good & normal & good & very good \\
\hline
\end{tabular}

Fig. 1. The questionnaire sample

athletic category and the top achievements at the All-Ukrainian and international levels. The procedure involves answering ten questions by circling one relevant statement.

The first four questions are aimed at obtaining general information about the level of an athletes' self-realization (satisfaction with personal sports career, promptness of the set of new sports goal after achieving the previous one, clearness of envisaging of sports career, self-
O.I. Рассказової), Опитувальник самоорганізації діяльності (ОСД) О.Ю. Мандрикової, Тест “Смисложиттєвих орієнтацій" (“СЖО”) Дж. Крамбо та Л. Махоліка (адаптація Д. О. Леонтьєва).

Для досягнення поставлених перед емпіричним дослідженням завдань, за яким визначалися чинники спортивної самореалізації паралімпійців ми розробили опитувальник, спрямований на визначення 
Опитувальник, спрямований на визначення рівня та чинників самореалізації у спортивній діяльності

ПІБ

вік

стать вид спорту

Стаж занять Спортивне звання

Найвище досягнення на всеукраїнському рівні

Найвище досягнення міжнародному рівні

ІНСТРУКЦІЯ: Будь ласка, дайте відповіді на нижченаведені запитання, обвівши кружечком відповідне твердження (тільки одне із запропонованих, що найбільше підходить за кожним запитанням).

\begin{tabular}{|c|c|c|c|c|c|c|}
\hline № & Запитання & & Bap & анти відповід & & \\
\hline 1 & $\begin{array}{l}\text { Чи задоволені Ви } \\
\text { власною спортивною } \\
\text { кар'єрою }\end{array}$ & $\begin{array}{c}\text { не } \\
\text { задоволений (a) }\end{array}$ & $\begin{array}{c}\text { швидшеше не } \\
\text { задоволений }\end{array}$ & $\begin{array}{c}\text { важко } \\
\text { відповісти }\end{array}$ & $\begin{array}{c}\text { швидшеше } \\
\text { задоволений }\end{array}$ & $\begin{array}{c}\text { повністю } \\
\text { задоволений }\end{array}$ \\
\hline 2 & $\begin{array}{l}\text { Після досягнення } \\
\text { спортивної мети як } \\
\text { швидко Ви ставите } \\
\text { наступну }\end{array}$ & не ставлю взагалі & $\begin{array}{c}\text { через тривалий } \\
\text { час }\end{array}$ & $\begin{array}{c}\text { через певний } \\
\text { час }\end{array}$ & $\begin{array}{c}\text { досить } \\
\text { швидко }\end{array}$ & $\begin{array}{l}\text { майже } \\
\text { відразу }\end{array}$ \\
\hline 3 & $\begin{array}{l}\text { Наскільки чітко Ви } \\
\text { уявляєте своє спортивне } \\
\text { майбутнє }\end{array}$ & ніяк не уявляю & $\begin{array}{c}\text { майже не } \\
\text { уявляю }\end{array}$ & $\begin{array}{l}\text { у загальних } \\
\text { рисах }\end{array}$ & $\begin{array}{c}\text { в основному } \\
\text { уявляю }\end{array}$ & $\begin{array}{c}\text { чітко } \\
\text { уявляю }\end{array}$ \\
\hline 4 & $\begin{array}{l}\text { Чи вважаєте Ви, що } \\
\text { досягли вершини } \\
\text { досягнень у спорті }\end{array}$ & $\begin{array}{l}\text { далеко не } \\
\text { досягнув }\end{array}$ & $\begin{array}{l}\text { частково } \\
\text { досягнув }\end{array}$ & $\begin{array}{c}\text { значною } \\
\text { мірою }\end{array}$ & $\begin{array}{c}\text { майже } \\
\text { досягнув }\end{array}$ & $\begin{array}{l}\text { повністю } \\
\text { досягнув }\end{array}$ \\
\hline 5 & $\begin{array}{l}\text { Ваші стосунки з } \\
\text { членами спортивної } \\
\text { групи/команди } \\
\end{array}$ & погані & $\begin{array}{l}\text { не дуже } \\
\text { хороші }\end{array}$ & нормальні & хороші & $\begin{array}{c}\text { дуже } \\
\text { хороші }\end{array}$ \\
\hline 6 & $\begin{array}{l}\text { Ваші стосунки } 3 \\
\text { тренером (тренерами) }\end{array}$ & погані & $\begin{array}{l}\text { не дуже } \\
\text { хороші }\end{array}$ & нормальні & хороші & $\begin{array}{c}\text { дуже } \\
\text { хороші }\end{array}$ \\
\hline 7 & $\begin{array}{l}\text { Ваші стосунки } 3 \\
\text { допоміжним } \\
\text { персоналом }\end{array}$ & погані & $\begin{array}{l}\text { не дуже } \\
\text { хороші }\end{array}$ & нормальні & хороші & $\begin{array}{c}\text { дуже } \\
\text { хороші }\end{array}$ \\
\hline 8 & $\begin{array}{l}\text { Ваша зацікавленість } \\
\text { в заняттях спортом }\end{array}$ & низька & $\begin{array}{c}\text { не дуже } \\
\text { висока }\end{array}$ & середня & висока & $\begin{array}{c}\text { дуже } \\
\text { висока }\end{array}$ \\
\hline 9 & $\begin{array}{l}\text { Вважаю своє } \\
\text { матеріальне становище }\end{array}$ & поганим & $\begin{array}{l}\text { не дуже } \\
\text { хорошим }\end{array}$ & $\begin{array}{c}\text { нормаль } \\
\text { ним }\end{array}$ & хорошим & $\begin{array}{c}\text { дуже } \\
\text { хорошими }\end{array}$ \\
\hline 10 & $\begin{array}{l}\text { Вважаю свої побутові } \\
\text { умови }\end{array}$ & поганими & $\begin{array}{c}\text { не дуже } \\
\text { хорошими }\end{array}$ & $\begin{array}{c}\text { нормаль } \\
\text { ними }\end{array}$ & хорошими & $\begin{array}{c}\text { дуже } \\
\text { хорошими }\end{array}$ \\
\hline
\end{tabular}

Рис. 1. Дослідницький бланк опитувальника

esteem of achievability of the pinnacle of sports performance).

Other six questions focus on the identification of the key factors of the self-realization of athletes (relations with members of sports group/team, coaches and support staff, interest in workout, financial standing and living conditions). рівня та чинників самореалізації у спортивній діяльності Опитувальник може бути використано для роботи як зі спортсменами, які мають інвалідність, так і зі здоровими спортсменами (Шамич, 2020). Дослідницький бланк опитувальника наведено нижче (рис. 1). 
General characteristics of sports selfrealization of Paralympic athletes under study are analyzed following the first four questions of the questionnaire intended to determine the level and factors of self-realization in sports:

1. Satisfaction with the personal sports career.

2. How rapidly do you set a new sporting goal after the achievement of the intended one?

3. How firmly do you envisage your sports career?

4. Have you reached the pinnacle of sports achievement?

\section{Results and discussion}

The findings confirm that Paralympic athletes under study (both male and female) - members of the national teams of Ukraine in different sports - are predominantly satisfied with their sports career - $81.0 \%$ of them are almost or completely satisfied. Only $6.0-7.0 \%$ gave one of the three others answer options (varying from "dissatisfied" to "difficult to answer").

They are generally characterized by a quite prompt set of a new sports goal. Only 3\% answered they don't set a new goal or set it after a while. In contrast, $80 \%$ of Paralympic athletes set their new goal rather quickly or almost immediately after reaching the previous one.

The fact that $87.0 \%$ of Paralympic athletes have a clear idea of their athletic future noting that they "tend to envisage it" or "have a clear picture of it" is logically agreed with the previous indicators. Once again, only 3\% circled two polar answer options, which characterize the ambiguity of such an idea.

Thus, as for the general characteristics of Paralympic athletes' self-realization in sports, it is established that predominant satisfaction with their sports career, a quite rapid set of a new sports purpose and clear vision of the athletic future is peculiar to both female and male Paralympic athletes. It stands to reason that most of them don't regard the achieved sports results as high as possible, because they realize their potential for further sports development.

Taking into account different age and the level of sports achievements of participants, there is a significant variation in the answer options concerning the crown of their results. About a third
Демографічна частина опитувальника призначена для отримання інформації про вік, стать, вид спорту, стаж занять, спортивне звання та найвищі досягнення досліджуваного на всеукраїнському та міжнародному рівнях. В інструкції пропонується надати відповіді на десять запитань, помітивши одне 3 п'яти тверджень, що найбільше підходить.

Перші чотири питання спрямовані на отримання загальної інформації про рівень самореалізації спортсменів (задоволеність власною спортивною кар'єрою, швидкість постановки нової спортивної мети після досягнення попередньої, чіткість уявлення свого спортивного майбутнього, самооцінку власної наближеності до вершини досягнень у спорті).

Ще шість питань спрямовані на визначення основних чинників самореалізації спортсменів (стосунки з членами спортивної групи/ команди, тренерами та допоміжним персоналом, зацікавленість у заняттях спортом, матеріальний стан та побутові умови).

Загальні особливості спортивної самореалізації досліджуваних паралімпійців нами аналізувалися за першими чотирма запитаннями опитувальника спрямованого на визначення рівня та чинників самореалізації у спортивній діяльності:

1. Задоволеність власною спортивною кар'єрою;

2. Як швидко після досягнення спортивної мети ставиться наступна;

3. Чіткість уявлення свого спортивного майбутнього;

4. Чи досяг вже вершини досягненьу спорті (Шамич, 2020).

\section{Результати та дискусії}

Отримані результати свідчать, що для досліджуваних паралімпійців, як для чоловіків, так і для жінок - членів збірних команд України з різних видів спорту властива переважна задоволеність власною спортивною кар'єрою - 81.0 \% 3 них нею переважно або повністю задоволені. Лише 6.0-7.0 \% надали один з трьох інших варіантів відповіді (від “не задоволений” до “важко відповісти”).

Для них загалом властива достатньо швидка постановка нової спортивної мети. Так те, що ця мета ними не ставиться, або ставиться лише 
Gender peculiarities of Paralympic athletes' self-realization

of them believe that they have not reached the top of their achievements yet or reached partially. And more than a quarter of them are convinced that they have almost or completely reached the top.

During the analysis of findings, the author has considered a natural heterogeneity of the sample - following gender, age, disability type, sports and sports achievements available at the moment of the research (some participants have already taken the winning places at the Paralympic or Deaflympic Games, and others haven't). Groups of the participants selected according to gender do not differ significantly under the first four points of the questionnaire.

It is also established that the interest of Paralympic athletes in a workout has the most pronounced manifestation among the distinguished six factors, which may determine the level of sports achievements of Paralympic athletes. The interpersonal relations of Paralympic athletes with other subjects of their sporting activity - members of their team, coaches and support staff - are mostly favorable. The vast majority of Paralympic athletes don't feel concerned about their financial standing. However, for $20.0 \%$ who evaluates it as not very good or bad, it can affect the progress in the training and competitive process. The level of satisfaction with the living conditions $(27.0 \%$ consider such conditions as bad or not very good) turned out to be a worse factor for sports activity.

When comparing the answers relating to six aspects of the questionnaire, which characterize the factors of sports achievements of Paralympic athletes according to gender, there were no significant differences.

The author has analyzed the subjective significance of external and internal factors for Paralympic athletes as stimulus for the workout following ten indicators of the self-esteem scale. Taking into account the specifics and tasks of the research, it has been used the modification of this method developed by 0 . Kokun, B. Ochepetko et al. for sports studies.

As O. Kokun states, the self-esteem scale makes it possible to receive the participants' assessment of different characteristics promptly and precisely. Its distinct advantages are flexibility, convenience,

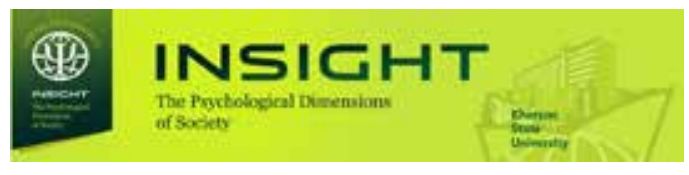

через тривалий час, зазначили лише $3 \%$. На противагу цьому 80 \% паралімпійців свою нову мету в спорті визначають досить швидко, або майже відразу після досягнення попередньої.

Досить логічно із попередніми показниками узгоджується й те, що 87.0 \% паралімпійців досить чітко уявляють своє спортивне майбутнє, відзначаючи, що таке уявлення в них “в основному наявне", або “чітко наявне". I знову лише 3.0 \% позначили два полярні варіанти відповіді, які характеризують нечіткість подібного уявлення.

Таким чином, щодо загальних особливостей спортивної самореалізації паралімпійців установлено, що для паралімпійців, як чоловіків, так і жінок у цілому властива переважна задоволеність власною спортивною кар'єрою, достатньо швидка постановка нової спортивної мети та досить чітке уявлення свого спортивного майбутнього. Також природно, що значна їх частина не вважає наявні спортивні досягнення гранично можливими, вбачаючи в собі потенціал для подальшого спортивного удосконалення (Шамич, 2018; 2020).

Природним, з огляду на різний вік і рівень спортивних досягнень досліджуваних, є досить значний розкид показників у відповідях щодо того, чи досягли вони вже вершини досягнень у спорті. Приблизно третина з них вважають, що далеко ще не досягли вершини досягнень, або досягли лише частково. А трохи більше чверті переконані, що такої вершини вони майже, або повністю досягли.

Під час аналізу отриманих результатів нами враховувалася природна неоднорідність вибірки - за статтю, віком, типом інвалідності, видами спорту та наявними на момент дослідження спортивними досягненнями (частина досліджуваних уже займали раніше призові місця на Паралімпійських чи Дефлімпійских іграх, а частина - ні). Групи досліджуваних, виділені за ознаками статі за першими чотирма питаннями опитувальника істотно не відрізняються.

Також встановлено, що серед виділених шести чинників, що можуть зумовлювати рівень спортивних досягнень паралімпійців, найбільш виражений позитивний вияв має зацікавленість паралімпійців у заняттях спортом. Також переважно сприятливими 
reliability, descriptiveness, express-character as well as the option to classify and compare the indicators obtained (Kokun, 2004).

At the same time, the author has considered six factors (enjoyment of workout, physical activities, moral satisfaction of the victory in the competitions; an option of personal self-realization, an opportunity to represent the native country, club, city; communication with friends, acquaintances; opportunity to improve or compensate for health conditions) as predominantly inner stimulus and other four indicators (an opportunity or prospect of overseas trips; financial incentives - salary, food, salary bonuses etc.; gaining of experience, acquaintances etc. that can contribute to further life outcomes; an opportunity to be a full member of the society) - as relatively external stimuli.

Four in ten indicators of the self-esteem scale confirm the availability of statistically reliable gender differences (table 1).

At the same time, it is interesting to note that all four indicators, which differ between men and women, are higher among women. Thus, one can state that such subjective stimuli for workout as an opportunity to represent a native country, city, club; an opportunity or perspective of overseas trip; financial incentives - salary, uniform, salary bonus etc., an opportunity to be a full member of the society; are more relevant to female Paralympic athletes than male ones.

In the context of self-efficiency, when comparing various groups of Paralympic athletes,
$€$ міжособистісні стосунки паралімпійців з іншими суб'єктами їх спортивної діяльності членами своєї спортивної команди, тренерами та допоміжним персоналом. У переважної більшості паралімпійців рівень задоволеності матеріальним становищем занепокоєння не викликає. Однак для 20.0\%, що оцінюють його як не дуже хороше чи погане, це може стати несприятливим для успішного тренувально-змагального процесу чинником. Дещо гіршим для спортивної діяльності чинником виявився рівень задоволеності ними своїми побутовими умовами $(27.0 \%$ вважають такі умови поганими або не дуже хорошими).

Під час порівняння за шістьма питаннями опитувальника, які характеризують чинники спортивних досягнень паралімпійців, груп за ознаками статі теж істотних відмінностей встановлено не було.

Аналіз суб'єктивної значущості для досліджуваних паралімпійців зовнішніх та внутрішніх чинників як стимулів для занять спортом нами здійснювався за десятьма показниками методики шкалованої самооцінки. 3 урахуванням специфіки і завдань дослідження використано модифікацію цієї методики, розроблену О. Кокуном, Б. Очеретько та іншими для досліджень у спорті.

Як зазначає О. Кокун, шкалована самооцінка дає змогу швидко і досить точно отримувати оцінку досліджуваними різних характеристик. Ії̈ найбільш вагомими перевагами є універсальність, зручність, надійність, інформативність,

Table 1. Differences in the indicators of external and inner factors as workout stimuli between male $(n=84)$ and female $(n=22)$ Paralympic athletes

Таблиця 1. Відмінності за показниками зовнішніх та внутрішніх чинників в якості стимулів для занять спортом між паралімпійцями чоловічої $(n=84)$ та жіночої статі $(n=22)$

\begin{tabular}{|c|c|c|c|c|}
\hline \multicolumn{2}{|l|}{$\begin{array}{l}\text { Self-esteem } \\
\text { Самооцінка }\end{array}$} & $\begin{array}{c}\text { Men } \\
\text { Чоловіки }\end{array}$ & $\begin{array}{l}\text { Women } \\
\text { Жінки }\end{array}$ & $p \leq$ \\
\hline \multirow{2}{*}{$\begin{array}{l}\text { An opportunity to represent your country, club, city } \\
\text { Можливість представляти на змаганнях свою країну, } \\
\text { клуб, місто }\end{array}$} & $\overline{\mathrm{X}}$ & 82.5 & 92.5 & \multirow[b]{2}{*}{.05} \\
\hline & $S_{x}$ & 23.4 & 11.6 & \\
\hline \multirow{2}{*}{$\begin{array}{l}\text { An opportunity or prospect of overseas trips } \\
\text { Можливість або перспектива закордонних поїздок }\end{array}$} & $\overline{\mathrm{X}}$ & 80.4 & 88.1 & \multirow{2}{*}{.05} \\
\hline & $S_{x}$ & 25.4 & 14.9 & \\
\hline \multirow{2}{*}{$\begin{array}{l}\text { Financial incentives - salary, uniform, salary bonuses etc. } \\
\text { Матеріальні стимули - зарплата, форма, премії та ін. }\end{array}$} & $\bar{X}$ & 75.8 & 85.8 & \multirow{2}{*}{.05} \\
\hline & $S_{x}$ & 27.9 & 20.5 & \\
\hline \multirow{2}{*}{$\begin{array}{l}\text { An opportunity to be a full member of the society } \\
\text { Можливість бути повноцінним членом суспільства }\end{array}$} & $\overline{\mathrm{X}}$ & 80.2 & 90.9 & \multirow{2}{*}{.05} \\
\hline & $S_{x}$ & 25.9 & 19.6 & \\
\hline
\end{tabular}


it is found that they hardly vary according to the gender aspect.

In terms of psychological well-being, eight in ten showed statistically reliable $(p \leq .1-.001)$ gender differences (table 2).

The data outlined in the table demonstrate that women have better indicators according to all eight aspects (note that the scale "affect balance" is reverse). According to the author's opinion, it can be regarded as an outstanding example that an adverse influence of a complex of factors associated with the disability fact is notably critical for male Paralympic athletes than female ones. This fact needs a more thorough analysis and understanding as the performance contrast between healthy men and women is less noticeable.

As well as in the case of the before analyzed indicators of psychological well-being, Paralympic female athletes have higher indicators of selfdetermination (table 3).

The differences in the scale "autonomy" is more apparent and in the scale "self-expression" - експрес-характер, а також можливість класифікації та зіставлення отриманих показників (Кокун, 2004).

При цьому шість показників (задоволення від тренувань, фізичних навантажень; моральне задоволення від перемог на змаганнях; можливість особистісної самореалізації; можливість представляти на змаганнях свою країну, клуб, місто; спілкування с друзями, знайомими; можливість виправити чи компенсувати недоліки здоров'я) нами розглядалися як переважно внутрішні стимули, і ще чотири показники (можливість чи перспектива закордонних поїздок; матеріальні стимули - зарплата, харчування, премії та ін.; набуття досвіду, знайомств та ін., що може допомогти влаштуватися у подальшому житті; можливість бути повноцінним членом суспільства) - як відносно зовнішні стимули.

За чотирма з десяти показників методики шкалованої самооцінки було установлено наявність статистично достовірних статевих відмінностей (табл. 1).

Table 2. Differences between male $(n=84)$ and female $(n=22)$ Paralympic athletes in terms of psychological well-being

Таблиця 2. Відмінності за показниками психологічного благополуччя між паралімпійцями чоловічої $(n=84)$ та жіночої статей $(n=22)$

\begin{tabular}{|c|c|c|c|c|c|}
\hline № & $\begin{array}{c}\text { Scale } \\
\text { Шкала }\end{array}$ & & $\begin{array}{c}\text { Men } \\
\text { Чоловіки } \\
\end{array}$ & $\begin{array}{l}\text { Women } \\
\text { Жінки }\end{array}$ & $\mathbf{p} \leq$ \\
\hline \multirow{2}{*}{1} & Positive relations & $\overline{\mathrm{X}}$ & 58.2 & 63.1 & \multirow{2}{*}{.05} \\
\hline & Позитивні взаємини & $S_{x}$ & 8.5 & 12.2 & \\
\hline \multirow{2}{*}{2} & \multirow{2}{*}{$\begin{array}{l}\text { Autonomy } \\
\text { Автономія }\end{array}$} & $\overline{\mathrm{X}}$ & 56.2 & 59.2 & \multirow{2}{*}{ - } \\
\hline & & $S_{x}$ & 9.1 & 13.1 & \\
\hline \multirow{2}{*}{3} & \multirow{2}{*}{$\begin{array}{l}\text { Environmental mastery } \\
\text { Управління середовищем }\end{array}$} & $\overline{\mathrm{X}}$ & 57.8 & 63.0 & \multirow{2}{*}{.01} \\
\hline & & $S_{x}$ & 7.0 & 8.3 & \\
\hline \multirow{2}{*}{4} & \multirow{2}{*}{$\begin{array}{l}\text { Personal growth } \\
\text { Особистісне зростання }\end{array}$} & $\overline{\mathrm{X}}$ & 60.7 & 63.5 & \multirow{2}{*}{.1} \\
\hline & & $S_{x}$ & 6.2 & 10.1 & \\
\hline \multirow{2}{*}{5} & \multirow{2}{*}{$\begin{array}{l}\text { Purposes in life } \\
\text { Цілі в житті }\end{array}$} & $\overline{\mathrm{X}}$ & 63.5 & 69.9 & \multirow{2}{*}{.01} \\
\hline & & $S_{x}$ & 7.7 & 11.2 & \\
\hline \multirow{2}{*}{6} & \multirow{2}{*}{$\begin{array}{l}\text { Self-acceptance } \\
\text { Самоприйняття }\end{array}$} & $\overline{\mathrm{X}}$ & 57.2 & 60.2 & \multirow{2}{*}{0,1} \\
\hline & & $S_{x}$ & 7.3 & 10.9 & \\
\hline \multirow{2}{*}{7} & \multirow{2}{*}{$\begin{array}{l}\text { Affect balance } \\
\text { Баланс афекту }\end{array}$} & $\overline{\mathrm{X}}$ & 96.1 & 83.2 & \multirow{2}{*}{.001} \\
\hline & & $S_{X}$ & 18.4 & 15.9 & \\
\hline \multirow{2}{*}{8} & \multirow{2}{*}{$\begin{array}{l}\text { Meaning in life } \\
\text { Осмисленість життя }\end{array}$} & $\overline{\mathrm{X}}$ & 100.2 & 106.9 & \multirow{2}{*}{.01} \\
\hline & & $S_{X}$ & 9.7 & 15.9 & \\
\hline \multirow{2}{*}{9} & \multirow{2}{*}{$\begin{array}{l}\text { The human being as an open system } \\
\text { Людина як відкрита система }\end{array}$} & $\overline{\mathrm{X}}$ & 64.7 & 64.6 & \multirow{2}{*}{-} \\
\hline & & $S_{X}$ & 6.4 & 10.7 & \\
\hline 10 & $\begin{array}{l}\text { Psychological well-being } \\
\text { Психологічне благополуччя }\end{array}$ & $\overline{\mathrm{X}}$ & 353.6 & 378.7 & .01 \\
\hline
\end{tabular}

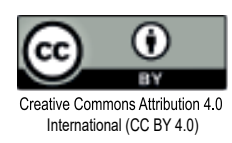


Table 3. Differences between Paralympic male $(n=84)$ and female $(n=22)$ athletes in terms of self-determination

Таблиця 3. Відмінності за показниками самодетермінації між паралімпійцями чоловічої статі $(n=84)$ та жіночої статі $(n=22)$

\begin{tabular}{|c|c|c|c|c|}
\hline \multicolumn{2}{|c|}{$\begin{array}{c}\text { Scale } \\
\text { Шкала }\end{array}$} & $\begin{array}{c}\text { Men } \\
\text { Чоловіки }\end{array}$ & $\begin{array}{l}\text { Women } \\
\text { Жінки }\end{array}$ & $p \leq$ \\
\hline \multirow{2}{*}{$\begin{array}{l}\text { Autonomy } \\
\text { Автономії }\end{array}$} & $\bar{X}$ & 38.4 & 41.4 & .05 \\
\hline & $S_{X}$ & 5.3 & 4.5 & \\
\hline \multirow{2}{*}{\begin{tabular}{|l} 
Self-expression \\
Самовираження
\end{tabular}} & $\overline{\mathrm{X}}$ & 40.0 & 42.5 & .1 \\
\hline & $S_{X}$ & 6.4 & 5.9 & \\
\hline
\end{tabular}

less. However, according to the author, they can't be considered as crucial.

\section{Conclusions}

1. Such subjective stimuli for workout as an opportunity to represent a native country, city, club; an opportunity or perspective of overseas trip; financial incentives - salary, uniform, salary bonus etc., an opportunity to be a full member of the society; are more important for female Paralympic athletes than male ones.

2. Paralympic male athletes have a statistically lower level of self-determination (the scales of "autonomy", "self-expression") and eight in ten indicators of psychological well-being.

3. A set of factors caused by the disability fact has a more adverse effect on male Paralympic athletes than female ones. The author believes it is commonly supposed that both healthy men and men with disabilities are leaders in their nature. A man is a family defender - he works, earns money and keeps a family. Even the top achievements don't bring a full moral satisfaction for Paralympic male athletes because the disability provides a kind of "barrier" they can't come to grips with under no circumstances.

\section{References:}

Boyko, G. M. (2012). Psychological and pedagogical accompaniment of sports activity of swimmers with disorders of psycho-physical development in Paralympic sports: monograph. Poltava: TOV ASMI.

Bpiskin, Yu. A. (2007). Theoretical and methodological bases of sports for the disabled as a component of the international Olympic movement. Extended abstract of Doctor's thesis. Kyiv.

Dad'ova, K. (2007). Introduction to adapted physical activities. Prague: Charles University.
При цьому, що цікаво, всі чотири показники, які у чоловіків та жінок відрізняються, $€$ вищими у жінок. Тобто можна стверджувати, що для жінок-паралімпійців $\epsilon$ істотно більш значущими за чоловіків такі суб’єктивні стимули занять спортом, як можливість представляти на змаганнях свою країну, клуб, місто; можливість або перспектива закордонних поїздок; матеріальні стимули - зарплата, форма, премії та ін.; можливість бути повноцінним членом суспільства.

За рівнем самоефективності, під час порівняння різних груп паралімпійців виявилося, що у статевому аспекті, вони майже не відрізняються.

За показниками психологічного благополуччя, зокрема, вісьма 3 десяти, встановлено наявність статистично достовірних ( $p$ s.01-.001), статевих відмінностей (табл. 2).

Наведені у таблиці дані показують, що всі ці вісім показників $\epsilon$ кращими у жінок (нагадуємо, що шкала “баланс афекту" є зворотною). Це, на нашу думку, можна вважати яскравим свідченням того, що для чоловіків-паралімпійців негативний вплив комплексу чинників, пов'язаних 3 наявністю інвалідності, є суттєво істотнішим, ніж для жінок, i, безумовно, потребує більш поглибленого аналізу та осмислення, оскільки нормативні відмінності між здоровими чоловіками та жінками є значно менш вираженими.

Як і у випадку з проаналізованими перед цим показниками психологічного благополуччя, показники самодетермінації також $\epsilon$ вищими у жінок-паралімпійців (табл. 3).

Дещо більш вираженими $є$ відмінності за шкалою “автономіï, меншими - за шкалою “самовираження". Однак, на нашу думку, їх не можна розглядати, як дуже принципові. 
Gender peculiarities of Paralympic athletes' self-realization

Kokun, O. M. (2004). Optimization of human adaptive capabilities: psycho physiological aspect of activity provision: Monograph. Kyiv: Millennium.

Lukovska, O., Kryshen, V., Golovachev, M., Maloyvan, Ya. \& Ovcharenko, S., (2017). Gender features of the psycho-emotional status of disabled athletes of the Paralympic and Deaflympic national teams of Ukraine in game sports. Sports Bulletin of the Prydniprovya, 2, 207-212.

Mariasova, D. A. Mental adaptation of disabled athletes with the defeat of the musculoskeletal system. Extended abstract of Candidate's thesis. Moscow.

Maslov, D. V, \& Rudovsky, A. A. (2011). Women in the Paralympic movement, dash to "psycho-logical portrait". Materials of the 1st All-Russian Congress "Medicine for Sports". Moscow, 269-276.

Ondrušova, Z., Pitekova, R., Bardiovsky, M., \& Galikova, Z. (2013). Sport and doing sports by the disabled posttraumatic return to life. Clinical Social Work, 2(4), 65-70/

Ovchapenko, S. V. (2005). Planning of the educational and training process of disabled football players with the consequences of cerebral palsy in the annual training cycle. Extended abstract of Candidate's thesis. Kyiv.

Semerjian, T. Z. (2010). Disability in Sport and Exercise Psychology. In T. V. Ryba, R. J. Schinke \& G. Tenenbaum (Eds.), The cultural turn in sport psychology. Fitness Information Technology (p. 257-265). West Virginia: Fitness Information Technology.

Serdyuk, L. Z. (2012). Psychology of motivation of learning of future specialists: system synergetic approach. Kyiv: University "Ukraine”.

Shamych, O. M. (2018). Comparative analysis of the level of development of current personal qualities of Paralympians and students. Technologies of intellect development. Vol. 2, 8 (19), Retrieved from: http://psytir.org.ua/index.php/technology_intellect_develop/article/view/331

Shamych, O. M. (2020). Psychology of self-realization of the personality in Paralympic sports. Extended abstract of Doctor's thesis. Kyiv.

Shamych, O. M (2018). The subjective significance of external and internal incentives to engage in sports by the Paralympians. Problems of modern psychology: a collection of scientific works of Kamianets-Podilskyi National Ivan Ohienko University, G. S. Kostiuk Institute of Psychology of the NAESciences of Ukraine, 41, 355-367.

Shuba, L. V. (2013). Pedagogical conditions of the organization of the educational and training process of the Paralympians with the defeat of the musculoskeletal system. Bulletin of the Chepnigiv National Pedagogical University. Pedagogical sciences. Physical Education and Sports, 112 (1), 357-360.

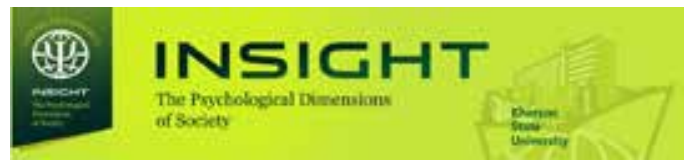

\section{Висновки}

1. Для жінок-паралімпійців $\epsilon$ істотно більш значущими за чоловіків такі суб'єктивні стимули занять спортом, як можливість представляти на змаганнях свою країну, клуб, місто; можливість або перспектива закордонних поїздок; матеріальні стимули - зарплата, форма, премії та ін.; можливість бути повноцінним членом суспільства.

2. У паралімпійців-чоловіків достовірно нижчий рівень показників самодетермінації (шкали “автономії”, “самовираження”) та восьми з десяти показників психологічного благополуччя.

3. Для чоловіків-паралімпійців негативний вплив комплексу чинників, пов'язаних 3 наявністю інвалідності, є суттєво істотнішим, ніж для жінок. Вважаємо, що як і у здорових людей, чоловіки в першу чергу відчувають себе лідерами. Чоловік - це захисник своєї родини, він працює, заробляє кошти і забезпечує родину. У паралімпійців-чоловіків навіть найвищі досягнення не дають повного морального задоволення, тому що інвалідність ставить певний “бар'єр”, з яким вони ні при яких обставинах змиритися не можуть.

\section{Список використаних джерел}

Бойко Г. М. Психолого-педагогічний супровід спортивної діяльності плавців із порушеннями психо-фізичного розвитку в паралімпійському спорті: монографія. Полтава: ТОВ АCMI. 2012. $360 \mathrm{c}$.

Бріскін Ю. А. Теоретико-методичні основи спорту інвалідів як складової міжнародного олімпійського руху : автореф. дис. ... д-ра наук з фіз. виховання і спорту: 24.00.01; К.: Національний ун-т фізичного виховання і спорту України. 2007. $40 \mathrm{c}$.

Dad'ova K. Introduction to adapted physical activities. Prague: Charles University. 2007. 134 c.

Кокун О. М. Оптимізація адаптаційних можливостей людини: психофізіологічний аспект забезпечення діяльності: Монографія. К.: Міленіум. 2004. 265 с.

Луковська О., Кришень В., Головачов М., Малойван Я., Овчаренко С.. Гендерні особливості психоемоційного статусу спортсменів-інвалідів паралімпійських і дефлімпійських збірних команд України з ігрових видів спорту. Спортивний вісник Придніпров'я, 2017, № 2, C. 207-212. 
Марьясова Д. А. Психическая адаптация спортсменов-инвалидов с поражением опорно-двигательного аппарата: автореф. дисс... канд. мед. наук: 14.01.06; 14.03.11. Москва. 2013. 24 с.

Маслов Д. В., Рудовский А. А. Женщины в паралимпийском движении, штрих к “психологическому портрету”. Материалы I Всероссийского конгресса "Медицина для спорта”. Москва, 2011, С. 269-276.

Овчаренко С. В. Планування навчально-тренувального процесу футболістів-інвалідів 3 наслідками дитячого церебрального паралічу в річному циклі підготовки: автореф. дис. ... канд. наук з фіз. виховання і спорту: 24.00.01. К. : Нац. ун-т фіз. виховання і спорту України. 2005. 24 с.

Ondrušova Z., Pitekova R., Bardiovsky M., Galikova, Z. Sport and doing sport $\mathrm{s}$ by the disabled posttraumatic return to life. Clinical Social Work, 2013. № 2(4), P. 65-70.

Semerjian T. Z. Disability in Sport and Exercise Psychology. The cultural turn in sport psychology. Fitness Information Technology [Tatiana V. Ryba, Robert J.Schinke and Gershon Tenenbaum (Eds.)]. West Virginia: Fitness Information Technology, Inc, 2010. P. 257-265.

Сердюк Л. 3. Психологія мотивації учіння майбутніх фахівців: системно синергетичний підхід. К.: Університет "Україна". 2012. 323 с.

Шамич О. М. Порівняльний аналіз рівня розвитку актуальних особистісних якостей у паралімпійців та студентів. Technologies of intellect development. 2018, Vol. 2, No 8(19) URL: http:// psytir.org.ua/index.php/technology_intellect_ develop/article/view/331.

Шамич О. М. Психологія самореалізації особистості в паралімпійському спорті: дис... докт. психол. наук: 19.00.01. К.: Інститут психології імені Г.С. Костюка НАПН України. 2020. 40 с.

Шамич О. М. Суб'єктивна значущість зовнішніх та внутрішніх стимулів занять спортом паралімпійцями. Проблеми сучасної психології: збірник наукових праць Кам'янець-Подільського національного університету імені Івана Огієнка, Інституту психології імені Г. С. Костюка НАПН України. 2018. Вип. 41, 355-367.

Шуба Л. В. Педагогічні умови організації навчально-тренувального процесу паралімпійців з ураженням опорно-рухового апарату. Вісник Чернігівського національного педагогічного університету. Серія: Педагогічні науки. Фізичне виховання та спорт, 2013, № 112(1). С. 357-360. 